University of Florida Levin College of Law

UF Law Scholarship Repository

1993

\title{
Transfer of Property by Inheritance and Bequest in Biblical Law and Tradition
}

Richard H. Hiers

University of Florida Levin College of Law, rhiers@ufl.edu

Follow this and additional works at: https://scholarship.law.ufl.edu/facultypub

Part of the Estates and Trusts Commons, and the Religion Law Commons

\section{Recommended Citation}

Richard H. Hiers, Transfer of Property by Inheritance and Bequest in Biblical Law and Tradition, 10 J. L. \& Religion 121 (1993), available at http://scholarship.law.ufl.edu/facultypub/737

This Article is brought to you for free and open access by the Faculty Scholarship at UF Law Scholarship Repository. It has been accepted for inclusion in UF Law Faculty Publications by an authorized administrator of UF Law Scholarship Repository. For more information, please contact kaleita@law.ufl.edu. 


\title{
TRANSFER OF PROPERTY BY INHERITANCE AND BEQUEST IN BIBLICAL LAW AND TRADITION
}

\author{
Richard H. Hiers*
}

\section{INTRODUCTION}

This topic is more complicated than one might suspect from reading typical annotations and bible dictionary articles. There are some hundred or so relevant biblical texts, but they do not present an entirely coherent picture. To take these texts seriously requires leaving open a number of questions. Too often commentators and annotators have attempted to resolve such questions by making assertions grounded upon highly problematic evidence. This article does not consider texts pertaining exclusively to the "inheritance" of the land of promise by the various tribes of Israel such as Joshua 11:23; 13:119:51; and Ezekiel 47:13 - 48:29. ${ }^{1}$ Concern with preserving tribal inheritances is in the background of some texts that are considered; but here attention is limited to laws and traditions concerning transfer of property from persons in one generation to those of another, or, in a few instances, to other persons within the same generation in accordance with what, in modern legal terms, would be called the laws of intestate succession and bequest. ${ }^{2}$

* Ph.D., Yale University; J.D., University of Florida; Professor of Religion and member, Doctoral Research Faculty, University of Florida. The writer wishes to thank particularly Professors Martin J. Buss and Raymond Westbrook for suggestions in connection with this study, and to remember the late Professor Theodor H. Gaster and Mr. Chief Justice Charles Longstreet Weltner who likewise kindly read earlier drafts and provided helpful comments. The writer, of course, bears sole responsibility for any errors herein.

1. On God's choice of certain biblical persons and their "seed" to be heirs to the land or his favor, see H.Z. Szubin and Bezalel Porten, Testamentary Succession at Elephantine, 252 Bull Am Sch Oriental Research 35, 37 (1983). Nor do we consider here the pseudepigraphic "testaments": The Testament of the Twelve Patriarchs, The Testament of Moses, and The Testament of Job. Other than in The Testament of Job (see below, text accompanying notes 115 . 16), there is no reference to property bequests in these "testaments." See generally, J.J. Collins, Testaments, in Michael E. Stone, ed, Jewish Writings of the Second Temple Period 325-55 (Fortress Press, 1984). Likewise, we do not here consider NT texts such as Matt. 19:29; 25:34; Mark 10:17; Eph. 1:13-14; Col. 3:24; and 1 Peter 1:4, where "inheriting" or "inheritance" refers to receiving or entering the coming Kingdom of God or messianic age. As to such usages, see C.E.B. Cranfield, Inherit, in Alan Richardson, ed, A Theological Word Book of the Bible 112-14 (Macmillan, 1978).

2. Similarly, we are not concerned here with biblical traditions regarding sons succeeding their fathers' office or status. On that topic, see David Daube, Sons and Strangers (Boston U Sch of Law, 1984). 
In what follows, we first review briefly the kinds of property subject to transfer by inheritance or bequest. Next, we examine texts pertaining to intestate succession-that is, transfer of property by operation of law upon the death of the property holder without explicit provision by will or bequest as to who will inherit or take afterwards. As a summary expression, such transfers will be designated as "inheritance." In this context, we note the relevance of certain provisions regarding levirate marriage and the Year of Jubilee. We also consider the problematic nature of the so-called birthright practice in this connection. Finally, we turn to a series of texts that appear to refer to bequests or deathbed wills, and also to inter-vivos gifts made by donors in anticipation of their eventual demise. The summary category for these latter types of transfers will be "bequests." A concluding section summarizes some probable conclusions and reviews a number of remaining open questions.

Three conclusions stand out in particular. First, an important distinction can be made between transfer of property by inheritance and transfer by bequest, legacy, or will-a distinction strangely absent in most scholarly discussions of relevant texts. Second, although relatively few scholars so conclude, there is persuasive evidence that in biblical times widows normally inherited property from their husbands. Whether their inherited property interest was equivalent to a fee simple absolute or some lesser possessory interest, such as usufruct or a life estate under Anglo-Saxon law, is not so certain. Finally, the concept of the "birthright" has commonly been misinterpreted. That institution seems to have been a precursor or adjunct to the law or practice of intestate succession. It is generally assumed that this concept meant that all first-born sons were to receive a double portion of their fathers' inheritance. But there is little evidence that this requirement was actually practiced during the biblical period.

\section{Property Subject to Transfer by Inheritance or BEQUEST}

Virtually all kinds of property appear to have been subject to transfer by inheritance or bequest. Provision for transferring real property (land, fields, and houses) was centrally important in biblical law and tradition. ${ }^{3}$ Wealth, generally, and certain particular forms of

3. See, for example, Gen. 48:21-22; Lev. 25:11-34; 27:16-25; Prov. 19:14; 23:10. Raymond Westbrook has convincingly demonstrated that in biblical times, in order to acquire an inheritable estate in real property, it was necessary to pay the "full price." Purchase of the Cave of Machpelah, 6 Israel L Rev 29, 29-38 (1971); The Price Factor in the Redemption of 
the same could be inherited or bequeathed, e.g., slaves, silver, gold, and cattle. ${ }^{4}$ Genesis traditions tell that Abraham gave "all that he had" to his son, Isaac. ${ }^{5}$ It has even been proposed that in the earliest form of levirate marriage, "the wife, being her husband's property, was passed on, like the rest of his estate, to his heir." No biblical texts indicate that wives, daughters or sisters were regarded as property subject to inheritance or bequest. However, 1 Kings 2:13-25 could be read to mean that Solomon regarded Abishag - his late father's bed-warmer, though at most, only nominally a concubine (1 Kings 1:1-4) - as royal property reserved for the heir to the throne. It may be that in the early monarchy the king's harem was inherited by his successor. ${ }^{7}$

\section{Inheritance: Descent of Property Through INTESTATE SUCCESSION}

\section{A. The Law of Intestate Succession}

Laws may be either written or unwritten. In the first instance, we can refer to texts setting out substantive provisions. Existence of unwritten laws can be inferred by observing customs and practices as recorded in narratives and other traditions. The basic biblical law of intestate succession is found in Numbers 27. But this written law evidently was supplemented by traditional practices long understood to have the force of law. ${ }^{8}$

Land, 32 R Intl des Droits de L'Antiquite, 3d Ser 97, 115-16 (1985). He cites such texts as Gen. 23:1-20 (cf 25:9-10); 33:19 (cf Joshua 24:32 which says that this land later "became an inheritance of the descendants of Joseph"); and Gen. 49:29-32; and 50:13. These essays have recently been reprinted in Raymond Westbrook, Property and the Family in Biblical Law (Sheffield, 1991).

4. See, for example, Lev. 25:46; 2 Chron. 21:3; Prov. 19:14; Judith 8:7.

5. Gen. 24:36; 25:5-6.

6. Cyrus H. Gordon, Fratriarchy in the Old Testament, $54 \mathrm{~J}$ Biblical Lit 223, 230 (1935); F. Charles Fensham, Widow, Orphan and Poor in Ancient Near Eastern Legal and Wisdom Literature, 21 J Near E Studies 129, 136 (1961). But see Millar Burrows, The Basis of Israelite Marriage 32 (Am Oriental Soc, 1938).

7. Roland de Vaux, Ancient Israel: Its Life and Institutions 115-17 (McGraw-Hill, 1961). See also the annotator, The New Oxford Annotated Bible with the Apocrypha 427 (Oxford U Press, 1991) ("NOAB-NRSV"). Also, see below, note 100.

8. Other ancient near eastern laws, known in the aggregate as "the cuneiform laws," may well have been familiar to legal/political leaders throughout the biblical period and so served as the unwritten or customary law of the land. See generally, Raymond Westbrook, The Law of the Biblical Levirate, $24 \mathrm{R}$ Intl des Droits de L'Antiquite, 3d Ser 63, 85-86 (1977), reprinted in Westbrook, Property and the Family at 69 (cited in note 3). It is unlikely; however, that all cuneiform law was considered authoritative in Israel; but where such known laws are apparently presupposed, they may well have been applied as customary law. While the substance of Israelite law is not necessarily unique, much of it may be distinctive. See John Van Seters, The 


\section{Sons}

It appears that in early times the norm was that sons inherited their fathers' property upon the latter's demise. ${ }^{9}$ The brief account in Joshua 17:3-6 concerning the daughters of Zelophehad clearly presumes that a father's property would normally pass to his sons. ${ }^{10}$ Zelophehad had no sons; so, apparently after his death, his daughters contended that they should be given their father's inheritance, and it was so ordered. The anecdote seems to presuppose the narrator's acquaintance with the episode described at Numbers 27:1-11, where the five daughters presented their claim to Moses, ${ }^{11}$ who brought it to Yahweh. Yahweh then not only ruled in their favor, but also set out the following law of intestate succession for all Israel:

And you shall say to the people of Israel, "If a man dies, and has no son, then you shall cause his inheritance to pass to his daughter. And if he has no daughter, then you shall give his inheritance to his brothers. And if he has no brothers, then you shall give his inheritance to his father's brothers. And if his father has no brothers, then you shall give his inheritance to his kinsman that is next to him of his family, and he shall possess it. And it shall be to the people of Israel a statute and ordinance, as the Lord commanded Moses." (Num. 27:8-11). ${ }^{12}$

Sons, if any, normally were implied to be the sole heirs (absent a sur-

Problem of Childlessness in Near Eastern Law and the Patriarchs of Israel, $87 \mathrm{~J}$ Biblical Lit 401, 401-08 (1968).

9. This pattern appears in instances where the sons' mothers are already deceased or are unmentioned. In cases where widows with sons are mentioned, the widows evidently inherited the property. See below, text accompanying notes 44-46.

10. See generally, J. Weingreen, The Case of the Daughters of Zelophehad, 16 Vetus Testamentum 518, 518-22 (1966).

11. One annotator comments, "The request of the daughters of Zelophehad was unusual in that, according to ancient law, normally women did not inherit property." The New Oxford Annotated Bible with the Apocrypha 200-01 (Oxford U Press, 1977) ("NOAB"); NOAB-NRSV at 204 (cited in note 7). The annotator neglects to tell us what that "ancient law" was or where it is to be found. Biblical tradition contains no such law.

12. Unless otherwise noted, translations quoted here follow the Revised Standard Version. Islamic law as set out in the Kur'an contained even more specific provisions. Under this law, each person or class of persons would receive a pre-determined fractional share of the estate (fara'id). See Suras 4:11-14, 176; 2:180, 240; and 5:106. Such provisions assumed and limited the power of testation. See generally, David S. Powers, On Bequests in Early Islam, 48 J Near E Studies 185, 185-200 (1989). Post-biblical Judaism introduced numerous supplements to the provisions of Numbers 27. See, for example, Arnold Bloch and Hyman Klein, trans \& eds, Maimonides' Laws of Inheritance (Shapiro, Vallentine \& Co, 1950); Dayan I. Grunfeld, The Jewish Law of Inheritance (Targum Press, 1987); Joseph Nissim, Rudiments of the Jewish Law of Inheritance Upon Intestacy and Bequests, Publications of the Society for Jewish Jurisprudence (Kelley \& Sons, 1931); Reuven Yaron, Gifts in Contemplation of Death in Jewish and Roman Law (Clarendon Press, 1960). 
viving widow) in numerous other biblical texts, e.g., Judges 11:1-2; 2 Chronicles 21:1-3; Proverbs 17:2; and Luke 12:13. But who are to be counted as "sons" for purposes of inheritance? Biblical traditions refer to the situation of sons by their fathers' concubines, their wives' maids, by slaves, and by harlots. It seems that any such sons might inherit, absent steps being taken to prevent their doing so.

Genesis 30 reports that Jacob had several sons by the maids of his wives Rachel and Leah, respectively, Bilhah and Zilpah. Rachel evidently regarded the arrangement with Bilhah as equivalent to what we might call surrogate motherhood. Thus she said to Jacob, "Here is my maid, Bilhah; go into her, that she may bear upon my knees, and even I may have children through her." (Gen. 30:3). Rachel regarded the sons subsequently born to Bilhah as her own, and she, Rachel, named them Dan and Naphthali. $(30: 6,8)$. Likewise, Leah named the sons Jacob had by her maid, Zilpah, Gad and Asher. (30:11-13). Rachel and Leah each gave these maids to Jacob "as a wife." $(30: 4,9)$. It would appear, however, that the wifely status of Bilhah and Zilpah was only nominal, and their status as maids primary. Thus in Genesis 35:23-26, Bilhah and Zilpah are described simply as the maids of Rachel and Leah. ${ }^{13}$ No tradition explicitly states that Dan, Naphthali, Gad, or Asher received an inheritance from Jacob. But these four are included among the "sons" whom Jacob "blessed" or "charged" shortly before his death. (Gen. 49:1-33). It may be inferred that they were to receive their "inheritances" along with the other brothers. ${ }^{14}$ Genesis $48: 5-6$ seems to say that all Joseph's brothers were to inherit from Jacob. Nothing here suggests that Dan, Naphthali, Gad, and Asher were to be excluded. Subsequent biblical tradition reports that their descendants received "inheritances" in the form of tribal allotments. (Joshua 13:24-28; 19:24-48).

The story about Sarai, Abram, Hagar, and Ishmael likewise suggests that a childless wife could "obtain children" by giving her maid

13. In Gen. 35:22, Bilhah is characterized merely as Jacob's "concubine."

14. See Van Seters, $87 \mathrm{~J}$ Biblical Lit at 405 (cited in note 8). Compare Code of Hammurabi $\S 170$, translated in D. Winton Thomas, Documents from Old Testament Times 33 (Harper \& Row, 1961), which reads:

If a citizen, whose wife has borne him children and (also) his bondmaid has borne him children, (and) the father during his lifetime has said to the bondmaid's children, which she has borne him, 'My children'; he has added them to the children of the wife. After the father goes to his fate, the children of the wife shall divide the property of the father's house equally with the sons of the bondmaid; the son and heir, the son of the wife, shall choose a share (first) and take it.

See also Code of Hammurabi $\S \S 145$ and 146, which apply only when a man ("citizen") has taken a priestess as wife. Id. 
to her husband "as a wife." (Gen. 16:1-3). ${ }^{15}$ The problem here was that Hagar was not content to serve merely as a surrogate mother, but acted rather as a wife and mother in her own right. (Gen. 16:4-6). It was Hagar, not Sarai, who would name her son Ishmael. (16:11). Ishmael is expressly described as Hagar's son $(21: 9,10,13)$ as well as Abram's son. (16:15-16; 21:11). As such, it seemed that he would inherit from Abraham. But Sarah objects and tells Abraham to send Hagar and Ishmael away, "for the son of this slave woman shall not be heir with my son Isaac." (21:10). Abraham reluctantly acquiesces. Apparently, if a man agreed, his wife could cause him to disinherit his son by her maid. ${ }^{16}$

Likewise, we see in Judges 11:1-2, that legitimate sons might, if they were able, drive off their father's son by a harlot and thus cause him to be disinherited. Implicitly, Jephthah would have inherited from his father if these half-brothers had not succeeded in forcing him out. ${ }^{17}$ Interestingly, whatever birthright may have meant, ${ }^{18}$ it does

15. Van Seters urges that unlike most other ancient Near Eastern law and custom, the biblical practice here attested was "clearly for the sake of the wife and not the husband." $87 \mathrm{~J}$ Biblical Lit at 403 (cited in note 8). See also Gerhard von Rad, Genesis: A Commentary 186 (Westminster, 1961). Von Rad suggests that under this arrangement the wife adopts the children borne by her maid. Id at 289.

16. A Harper's Bible Dictionary commentator takes Gen. 21:10 as evidence that in biblical times "the sons of a concubine did not inherit." Harper's Bible Dictionary 422 (Harper \& Row, 1985) ("HBD"). Likewise, The New Westminster Dictionary of the Bible 375-76 (Westminster, 1976) ("NWDB"). The point, however, is that Ishmael would have inherited had not Sarah insisted on, and Abraham agreed to, his banishment. See Van Seters, $87 \mathrm{~J}$ Biblical Lit at 403 (cited in note 8); and Otto J. Baab, Inheritance, in 2 The Interpreter's Dictionary of the Bible 701 (Abingdon, 1962) ("IDB"). See also Gen. 25:5-6, which says that Abraham gave all he had to Isaac, but also gave gifts to the sons of his concubines, which sons, "while he was still living he sent . . . away from his son Isaac, eastward to the east country." The probable implication is that Abraham sent these sons away so that they would not be around to claim a share of the inheritance he had given or bequeathed to Isaac. The New English Bible annotator, commenting on Gen. 21:8-21, asserts that "[a]ncient Near Eastern law stipulated that the offspring of a slave wife could either inherit with the children of the free woman or be set free." The New English Bible with the Apocrypha, Oxford Study Edition 20 (Oxford U Press, 1976) ("NEB"). Unfortunately the annotator does not mention which ancient Near Eastern law so provided. Possibly the annotator was thinking of the Lipit-Ishtar Law Code $\$ 25$, which reads:

If a man married a wife (and) she bore him children and those children are living, and a slave also bore children for her master (but) the father granted freedom to the slave and her children, the children of the slave shall not divide the estate with the children of their (former) master.

James B. Pritchard, ed, Ancient Near Eastern Texts 160 (Princeton U Press, 1950) ("ANET").

17. See Lipit-Ishtar Law Code $\$ 27$, which provided that if a man's wife had not borne him children, any children borne to him by a harlot would be his heirs. ANET at 160 (cited in note 16). Conversely, see Sirach 23:22, which suggests that the offspring born in the union between an adulterous wife and her lover would be her legal husband's heir. From the husband's standpoint, such an heir would likely be objectionable, and this scenario may in fact account for the strong biblical antipathy to adultery when committed by a wife. See generally, Raymond Westbrook, Adultery in Ancient Near Eastern Law, 97 Revue Biblique 542 (1990). 
not seem to have been a factor in the stories of either Ishmael or Jephthah, even though Ishmael was the first of Abraham's sons and Jephthah may have been the first son of his father.

One text, 1 Chronicles 2:34-35, suggests that a slave might serve as a surrogate father for purposes of perpetuating the family line. Having no son but only daughters, a certain Sheshan married one of them to his Egyptian slave. The son of this marriage then fathered a continuing succession of male descendants who, presumably, inherited whatever property Sheshan had to pass down to his heirs. (2:3641). ${ }^{19}$

A few texts suggest that in the absence of other offspring, a slave might inherit, possibly as a "constructive" son, that is, a son by operation of law. ${ }^{20}$ Thus early in the Abraham cycle, Abram complains that God has given him no offspring, with the result that a slave born in his house would be his heir. (Gen. 15:3) ${ }^{21}$ The phrasing implies that a slave born in the house of an otherwise childless father would be counted as a son. Yahweh therefore assures Abram that the slave born in his house would not be his heir; instead, Abram's own son would be his heir. (15:4). The $N O A B$ and $N E B$ annotators suggest that this text may presuppose the practice attested in Nuzi, whereby "a slave could be adopted as the heir in case of childlessness." 22

18. See below, text accompanying notes 87-105.

19. See also Thomas and Dorothy Thompson, Some Legal Problems in the Book of Ruth, 18 Vetus Testamentum 79, 87 (1968): "Through this marriage Sheshan himself obtained sons and heirs."

20. Perhaps the underlying consideration in Gen. 15:3-4 was that a slave born in his master's house could be presumed to have been fathered by the master-an early version of the doctrine, res ipsa loquitur. But see William Blackstone, 2 Commentaries on the Laws of England 12 (Strahan, 9th ed, 1783). Commenting on Gen. 15:3-4, Blackstone conjectured that the practice there attested had derived as follows:

A man's children or nearest relations are usually about him on his death-bed, and are the earliest witnesses of his decease. They became therefore generally the next immediate occupants, till at length in process of time this frequent usage ripened into general law. And therefore also in the earliest ages, on failure of children, a man's servants born under his roof were allowed to be his heirs, being immediately on the spot when he died.

Compare Prov. 17:2 and 29:21 which also may refer to slaves inheriting from their masters.

21. It is not entirely clear from the context whether this slave was Eliezer of Damascus who was characterized in the preceding verse as the heir of Abram's "house." It is possible that Eliezer was an otherwise unidentified kinsman of Abram's who would have inherited under the kind of custom institutionalized in Num. 27:11. There is no mention of Eliezer in Abraham's family tree in Gen. 11:24-28.

22. $N O A B$ at 17 (cited in note 11 ); $N E B$ at 14 (cited in note 16). Von Rad suggests that Abraham may have been cognizant of such practice, noting that Nuzi texts included "several contracts, according to which in the event of childlessness slaves were adopted; their duty then was to give the testator proper burial." Genesis at 178-79 (cited in note 15). See also Cyrus H. Gordon, Biblical Customs and the Nuzi Tablets, in Edward F. Campbell, Jr., and David Noel 
Nothing is said in Genesis 15:2-4; however, about adoption. ${ }^{23}$ Here it seems to be enough for the slave to have been born in Abram's "house."

\section{Daughters}

The law of intestate succession in Numbers 27:8 provides that if a man has no son, "his inheritance [shall] pass to his daughter." Reference to "his daughter" might be read to mean that only one daughter, perhaps the older or oldest, would inherit. However, the accompanying narrative, Numbers 27:1-7, and also Joshua 17:3-6, make it clear that all five of the daughters of Zelophehad were to, and did inherit their father's property. Read in this context, Numbers 27:8 therefore probably should be understood to refer to daughter or daughters, if more than one.

According to Genesis 31:14-16, Rachel and Leah evidently expected to receive an inheritance from their "father's house" even though he also had sons. (31:1). Possibly daughters did inherit under Syrian law, at least if they were older than their brothers. It has been suggested that pursuant to practices attested at Nuzi, Laban had adopted Jacob, and that this relationship is in the background of their property transactions and other dealings. ${ }^{24}$ The women's complaint that their father, Laban, had been "using up the money given for us" $(31: 15)$ could refer to their dowry, ${ }^{25}$ which may have been in addition to their expected inheritance. ${ }^{26}$

Apart from these instances, there seem to be no other biblical texts reporting daughters inheriting or expecting to inherit from their

Freedman, eds, 2 The Biblical Archaeologist Reader 22-23 (Anchor-Doubleday, 1964). Compare Code of Hammurabi $\S 170$, (cited in note 14), which provides that a man may adopt sons borne him by a bondmaid or maid servant.

23. Daube suggests that traditions regarding adoption were deleted from biblical materials as part of Nehemiah's and Ezra's program of restoring family purity. Daube, Sons and Strangers at 48 (cited in note 2).

24. Campbell and Freedman, 2 Biblical Archaeologist at 24-27 (cited in note 22). It has also been suggested that Jacob's relations with Laban and his family evidence a pattern of matrilineal descent. Nancy Jay, Sacrifice, Descent, and the Patriarchs, 38 Vetus Testamentum 52, 59-64 (1988).

25. See generally Burrows, The Basis of Israelite Marriage at 41-46 (cited in note 6) and Westbrook, Property and the Family at 149-50, $157-58$ (cited in note 3). Westbrook points out that there is "repeated evidence" in cuneiform law that a daughter could inherit from her father's estate. Id at 158-64.

26. See A.M. Brown, The Concept of Inheritance in the Old Testament, unpublished Ph.D. dissertation, Colum U, 1965, 10-11, cited in Donald A. Leggett, The Levirate and Goel Institutions in the Old Testament: with Special Attention to the Book of Ruth 215, n 21 (Mack Pub, 1974). 
parents. ${ }^{27} \mathrm{~A}$ few gender neutral expressions could be read to mean, in effect, inheritance by sons and/or daughters, but none necessarily bears that meaning. ${ }^{28}$

In the story of Tobit, apparently contrary to the law of intestate succession set out in Numbers 27, when Tobias' mother-in-law and father-in-law died, their daughter, Sarah, evidently their only child, ${ }^{29}$ did not inherit their property. Instead, Tobias, Sarah's husband, inherited it. (Tobit 14:12-13). Perhaps only unmarried daughters of sonless fathers inherited from their fathers. This conclusion accords with the further legislation concerning the daughters of Zelophehad set out in Numbers 36.

Numbers 36 is concerned, in the first instance, to make sure that each of the tribes of Israel would preserve its own original inheritance as allotted in the days of Joshua. Lest inheritances be transferred from one tribe to another (36:9), the following provision was added concerning heiresses:

[E]very daughter who possesses an inheritance in any tribe of the people of Israel shall be wife to one of the family of the tribe of her father, so that every one of the people of Israel may possess the inheritance of his fathers. (Num. 36:8).

The clear implication is that when a woman who had inherited her father's property married, the inherited property then became her husband's. Tobias's inheriting from his in-laws is only a corollary to

27. Job 42:15 says that Job gave his daughters inheritances along with their brothers. The likely meaning here is that he gave them property by bequest, not that they received these "inheritances" by intestate succession. See below, text accompanying notes 117-18. It is not clear whether Sheshan's daughters would have inherited his property if none of them had married and had children. 1 Chron. 2:34-41. Their father saw to it that one of them did marry; the resulting line of male progeny presumably inherited. On daughters' status as heirs in other ancient Near Eastern cultures, see Zafrira Ben-Barak, Inheritance by Daughters in the Ancient Near East, 25 J Semitic Studies 22, 22-23 (1980).

28. Otto J. Baab points out that the Septuagint version of the law of levirate marriage in Deut. 25:6 reads "child" (to paidion) rather than "first son." 2 IDB at 702 (cited in note 16). This change may suggest that the Septuagint editor intended the text to be read so that a firstborn daughter could be the deceased's heir under terms of levirate marriage, at least if there were no later-born sons. On the basis of Septuagint evidence (Deut. 25:5, 6), Westbrook concludes that "the most likely hypothesis is that until late biblical times at least, the existence of a daughter did not affect the imposition of the levirate, nor was the birth of a daughter considered fulfillment of the duty." Westbrook, The Law of the Biblical Levirate, $24 \mathrm{R}$ Intl des Droits de L'Antiquite, 3d Ser at 79 (cited in note 8), reprinted in Westbrook, Property and the Family at 69 (cited in note 3). See also: Psalms 25:13 (the "children" of the righteous man shall "possess the land"); Prov. 19:14 ("House and wealth are inherited from fathers"); and Prov. 23:10 ("Do not remove an ancient landmark or enter the fields of the fatherless").

29. According to Tobit 6:10-11, Sarah was her parents' only daughter and heir. If she had brothers, they, presumably, would have inherited under the provisions of Num. 27:8-11 and Sarah would have taken nothing. 
this provision, showing that if a married woman inherited from her parents, the inheritance would then pass to her husband..$^{30}$

The writer of Tobit evidently had some acquaintance with the provisions of Numbers 36, but greatly exaggerated the latter's scope and penalties. As Tobias and the angel Raphael came near to Ecbatana, the angel, a/k/a "Brother Azarias," tells Tobias that as her "only eligible kinsman," he is entitled to marry her and to receive her inheritance. (6:11). It is just barely possible that there were no other men left in the whole tribe of Naphtali to which Tobias belonged, ${ }^{31}$ but extremely unlikely, even allowing for the untimely demise of Sarah's previous seven would-be husbands who all, presumably, also had been eligible kinsmen and Naphtalites. ${ }^{32}$ According to Numbers 36:6, the daughters of Zelophehad could marry whomever they thought best, provided the husbands came from their tribe. ${ }^{33}$ Heiresses were not required to marry their nearest kinsman. Thus it is probably an overstatement to say that Tobias alone was entitled to marry Sarah and receive her inheritance. ${ }^{34}$ Likewise, the angel's claim that, under the law, Sarah's father would incur the death penalty if he gave Sarah to any other man (Tobit 6:12) must be regarded as literary or dramatic hyperbole.

\section{Widows}

Widows were not provided for in the law of intestate succession in Numbers 27. As we shall see, a widow could receive her husband's property by bequest. (Judith 8:7). But absent such bequest, might she inherit his property by operation of law? Several texts suggest that she could inherit his real property.

One such text is Ruth 4:3. Boaz tells the late Elimelech's nearest kinsman that the widow, Naomi, "is selling the parcel of land which

30. Tobit $14: 13$. See below note 47 and accompanying text.

31. Tobit $1: 1,4,5 ; 7: 3$.

32. Conceivably, the narrarator may have been thinking of levirate marriage tradition, under which the nearest surviving male kinsman had the right (or duty) to marry the sonless deceased's widow. See below notes 52-70 and accompanying text.

33. More precisely, such heiresses were to marry within "the family" of their father's tribe. Westbrook suggests that this concept meant that heiresses were likely to marry relatives no more remote than "cousins." See Westbrook, Property and the Family at 22, 163-64 (cited in note 3 ).

34. According to Tobit 8:20-21, Raguel, Tobias' father-in-law, promised to give Tobias half his property at the end of the wedding feast, and the rest when he (Raguel) and his wife died. This promise, under oath, could be viewed either as a will or as part of the marriage contract. But if, under customary law, Tobias was entitled to receive his in-laws' property upon their death anyway by virtue of having married their only daughter, the promise merely confirmed that right. 
belonged to our kinsman Elimelech." 35 It is reasonable to infer that if she was selling it, title must have passed to her by operation of the law upon the death of her husband, Elimelech, ${ }^{36}$ unless, of course, he had bequeathed it to her. ${ }^{37}$ Other features of the book of $R$ uth likewise support the conclusion that Naomi had inherited some or all of her deceased husband's property. ${ }^{38}$

In cases (to be considered shortly) where a widow with a son (or sons) appears to inherit the decedent's property, it might be argued that the property was hers only as trustee, pending her son's reaching the age of majority. In Ruth, however, Naomi has no living sons and no one expects her to have any. There can be no question of Naomi's

35. Ruth 4:3; see also Ruth 4:5, the Hebrew text of which, translated literally, reads, "What day you buy the field from the hand of Naomi and from Ruth the Moabitess, you have bought the wife of the dead to raise up the name of the dead upon his inheritance." Translation by David Daube, Ancient Jewish Law 39 (Brill, 1981). Cf the King James Version. From this version, it could be inferred that Ruth had inherited a portion of her father's or late husband's estate. See, however, Ruth 4:9 where Boaz says he has bought the land "from the hand of Naomi," with no mention of Ruth's ownership.

36. Raymond Westbrook has urged that Ruth $4: 3$ be understood to mean that Naomi had already sold the property to a third party. Redemption of Land, 6 Israel L Rev 367, 373-75 (1971), The Price Factor in the Redemption of Land, 32 R Intl des Droits de L'Antiquite, 3d Ser at 126 (cited in note 3). Both essays have been reprinted in Westbrook, Property and the Family (cited in note 3). He suggests that Elimelech or Naomi had sold the land at discount before leaving for Moab, and that in Ruth 4, it is a matter of redeeming this land from the third party. But Ruth $4: 5$ and 9 clearly say that the present purchase is from the hand of Naomi. Leggett argues persuasively against the theory that the land had already been sold. Levirate and Goel at 218-22 (cited in note 26). See also Millar Burrows, The Marriage of Boaz and Ruth, 59 J Biblical Lit 445, 446-47 (1940); De Vaux, Ancient Israel 166-67 (cited in note 7); and Jack M. Sasson, Ruth: A New Translation with Philological Commentary and a Formalist-Folklorist Interpretation 108-15 (Johns Hopkins U Press, 1979). It appears more likely that Naomi's land was subject to redemption because her husband and their sons had died, leaving her without other means of support, than because of some possible (but unmentioned) previous sale to a third party.

37. See Leggett, Levirate and Goel at 217 (cited in note 26); Edward F. Campbell, Jr., Ruth: A New Translation with Introduction, Notes, and Commentary, 7 The Anchor Bible 158 (Doubleday, 1975). Several legal issues arise in Ruth 4:1-12. See id at 154, referring to "the ocean of ink which has been spilled over ... unanswered questions" there. We do not attempt to solve those questions here, but only to note those relating to inheritance, and to suggest some possible conclusions.

38. See also Leggett, Levirate and Goel at 211-18 (cited in note 26). "The announcement, made in the presence of the lawfully assembled body, that Naomi was selling the property, went unchallenged; thus there can be little doubt that she was lawfully in possession of the property." Id at 218. See also Burrows, $59 \mathrm{~J}$ Biblical Lit at 448 (cited in note 36): "[W]e must admit that the book of Ruth assumes the practice of inheritance by widows .... At any rate our author assumes that his readers will not regard it as strange." Compare Sasson, Ruth: $A$ New Translation with Philological Commentary at 108-15, 117-20, 139-40 (cited in note 36). Sasson urges that although Naomi was in possession of the land and was selling it, she had not inherited it, but was holding it as Elimelech's land pending sale. When it was sold, however, she would be entitled to the proceeds. 
holding property as trustee for any sons. ${ }^{39}$ Therefore, she appears as owner of her late husband's property in her own right. She has had two sons, but they both predeceased her. Because the sons were grown and had survived their father, Elimelech, it is possible that at his death the sons had inherited from him. ${ }^{40}$ Then, when her sons died, Naomi would have inherited from them, ${ }^{41}$ or at least from Chilion, because Ruth might have inherited from Mahlon. This pattern of succession is intimated in Ruth 4:9, where Boaz declares "[t] his day I have bought from the hand of Naomi all that belonged to Elimelech and all that belonged to Chilion and to Mahlon." This sequence could also explain why in the Hebrew text of Ruth 4:5, Boaz tells the nearer kinsman that the field belongs to both Naomi and Ruth. Ruth may have inherited the portion that belonged to Mahlon, her late husband, while Naomi inherited Chilion's portion. Or, Naomi may have inherited the whole parcel from Elimelech. The evidence could lead to either conclusion. As a convenience, we shall refer to the parcel or field as Naomi's property.

It has been countered that, because Ruth "gleaned" in Boaz's field rather than Naomi's, we should conclude that Naomi no longer owned the field. Ruth 1:22, however, suggests another explanation: After many years' absence, Naomi and Ruth returned "at the beginning of the barley harvest." Naomi's field provided no harvest be-

39. De Vaux urges that Naomi was merely acting as the guardian of her deceased son's rights. Ancient Israel at 54 (cited in note 7). But see Westbrook, Redemption, 6 Israel L Rev at $372-73$ (cited in note 36 ).

40. Compare Westbrook, The Law of the Biblical Levirate, $24 \mathrm{R}$ Intl des Droits de L'Antiquite, 3d Ser at 65 (cited in note 8), reprinted in Westbrook, Property and the Family (cited in note 3). Here he seems to say that Boaz redeemed Mahlon's land, id at 66, but later concludes that neither Mahlon nor Chilion ever inherited the family property, id at 77 . Westbrook's theory is that either Elimelech (or Naomi, as his agent) had sold the land before moving to Moab. See also Westbrook, The Price Factor at 109-10, 126 (cited in note 3), where he suggests that the right of redemption arose only when the seller had been compelled to sell at discount because he had become poor. While Elimelech might have become poor and sold his land to a third party before moving to Moab, the text does not so indicate. Rather, it appears that it was the levirate law that prompted the transactions reported in $R u t h$ chap 4 . Westbrook has carefully described the connection between levirate and redemption law. "The levirate therefore works alongside redemption. Just as the right of redemption restores to the family property that is lost (or threatened to be lost) by alienation, so the duty of the levirate restores a family to its property from which it is separated by extinction of the male line." Redemption, 6 Israel L Rev at 372 (cited in note 36). The latter conditions evidently obtain in Ruth chap 4.

41. See D.R.G. Beattie, The Book of Ruth as Evidence for Israelite Legal Practice, 24 Vetus Testamentum 251, 254-55 (1974). The sons' estate could have been as yet undivided. See Westbrook, Property and the Family at 132-38 (cited in note 3). 
cause no one had planted it ${ }^{42}$ Moreover, three distinct texts, $R$ uth 4:3, 5, and 9, make clear that Naomi (if not also Ruth) owned the field that had belonged to the late Elimelech. The field was not the only property Naomi may have inherited from Elimelech. She also evidently had inherited the house in Bethlehem where she had lived with her husband and sons before sojourning in Moab. To be sure, no text specifically refers to Naomi's "house." But several texts suggest that Naomi resided in Bethlehem, most notably 2:23, which states that Ruth "lived with her mother-in-law" there. ${ }^{43}$

That widows inherited their deceased husbands' property is likewise evidenced in two different stories from the Elisha cycle. The first is 2 Kings 4:1-7, where Elisha helps a widow by causing her "cruse" of oil to keep flowing until it produced enough to pay off her debts. We cannot tell whether the widow inherited her husband's debts, but she did evidently inherit and continue to live in the family house with her sons. The story in 2 Kings 8:1-6 also apparently concerns a widow with a son; her husband, who was said to be old in 2 Kings 4:8-37, is not mentioned at all in 8:1-6, which refers several times to her house and land. ${ }^{44}$ It is reasonable to infer that her husband had died and that she had inherited his property ${ }^{45}$ A text in Proverbs also suggests that widows inherited their deceased husbands' fields or land: "The Lord tears down the house of the proud, but maintains the widow's boundaries." (Prov. 15:25). ${ }^{46}$ That a widow might inherit her hus-

42. See also Leggett, The Levirate and Goel at 219-20 (cited in note 26). But see Campbell, Ruth, The Anchor Bible at 157 (cited in note 37).

43. See also $R$ uth $1: 22 ; 2: 18 ; 3: 1-3,15-17$. None of these texts suggests that Naomi and Ruth lacked a dwelling place or had to live "on the street," or that they were guests in any one else's home. Burrows concludes that Naomi and Ruth lived in a house. $59 \mathrm{~J}$ Biblical Lit at 447 (cited in note 36). Sasson assumes that they lived in Naomi's "home." Ruth: A New Translation at 124 (cited in note 36 ). Houses evidently were inherited in biblical times. See Prov. 19:14; Micah 2:2; Mark 12:40= Luke 20:47.

44. 2 Kings $8: 3,5,6$.

45. It has been suggested that Naomi and the Shunammite widow of 2 Kings 4 and 8 might have held their deceased husbands' properties as trustees or executors rather than as owners. Millar Burrows, An Outline of Biblical Theology 302 (Westminster Press, 1946). By virtue of preeminence obtained either through birthright or a dying father's "blessing," a son might have authority to administer his father's undivided estate. See Westbrook, Property and the Family at 136-37 (cited in note 3). We find no evidence of trusteeship or estate administration by widows in biblical tradition; however, cuneiform laws do provide for something like such trusteeship arrangements. Whether a biblical widow with a son (or sons) "inherited" property from her husband or served as "trustee" after his death by operation of law may be largely a semantic question. In either event, she apparently held many of the "sticks" of ownership, including possession and control of the property at least during her son's (or sons") minority. It is completely unclear; however, when such sons may have attained "majority" or ownership themselves.

46. See also The Teaching of Amenope, 6:1-6, translated in Thomas, ed, Documents from 
band's property is also suggested in the story of Tobit. Raguel promises his son-in-law, Tobias, that he would receive the balance of his (Raguel's) property "when my wife and I die." (Tobit 8:20-21). The implication seems to be that if Raguel died first, his wife would inherit a life interest in the estate, which would then pass to Tobias only after her death. ${ }^{47}$ These biblical texts which indicate that widows inherited their husbands' real property accord with a number of ancient Near Eastern laws and reported decisions. ${ }^{48}$

For example, the Code of Hammurabi $\S \S 171-74$, provided that the bridegroom's gift to his bride would be used to support her and their children if the husband predeceased her, but that if he had not so provided for her, she was to be assigned a son's share in the deceased's estate. $^{49}$ There are no explicit biblical counterparts to these arrangements. However, it is quite conceivable that under common or "uncodified civil law" a widow would inherit from her husband. Such law need not have been contrary to the law of intestate succession in Numbers 27. That law may well have been meant to apply only if-as may generally have been the case-the son's mother had predeceased her husband. ${ }^{50}$ At all events, the biblical widow's interests were at least indirectly protected under the law or practice of levirate marriage. ${ }^{51}$

\section{B. Inheritance and Levirate Marriage}

The law of levirate marriage set out in Deuteronomy 25:5-10 fo-

Old Testament Times at 179 (cited in note 14). The Talmud later assumes that a husband inherits land from his wife. 14 Encyclopedia Judaica 581 (Keter Pub House, 1972). In Judges 17:1-4, we see that Micah's mother, who may have been a widow, was a person of some wealth, which she may have inherited from her husband. It is not clear whether she lived in her own house or in her son's house.

47. It could be inferred instead that Raguel and his wife owned their property jointly; but such joint property ownership arrangements are otherwise unknown in the Bible, and are rare in ancient Near Eastern tradition. But see Yochanan Muffs, Studies in the Aramaic Legal Papyri from Elephantine 33-34 n 3 (Brill, 1969).

48. See, for example, James B. Pritchard, The Ancient Near East 545-46 (Princeton U Press, Supp 1969) ("ANE"); Muffs, Studies at 33-34 n 3 (cited in note 47); Eryl W. Davies, Inheritance Rights and the Hebrew Levirate Marriage Part I, 31 Vetus Testamentum 138 (1981). Widows did not fare so well in post-biblical Jewish law. See Grunfeld, The Jewish Law of Inheritance 10-16 (cited in note 12).

49. Burrows, The Basis of Israelite Marriage at 47-48 (cited in note 6); De Vaux, Ancient Israel 54 (cited in note 7). As to Egyptian law ca. 1100 B.C.E., see Fensham, 21 J Near E Studies at 132-34 (cited in note 6); Van Seters, $87 \mathrm{~J}$ Biblical Lit at 405-06 (cited in note 8).

50. See Leggett, Levirate and Goel at 216-17 n 24-25 (cited in note 26). It may be more than merely coincidental that no biblical traditions report that sons or daughters inherited their father's property while his widow was still alive.

51. See also Davies, Inheritance Rights Part II at 257.68 (cited in note 48 ). 
cuses attention on perpetuating the sonless deceased "brother's name in Israel," that is, building up the deceased "brother's house" by providing him a "son." (25:6-9). This law does not refer explicitly to property or inheritance; however, it is generally agreed that one of its functions was to assure retention of ancestral property within the family or clan..$^{52}$ The story of Judah and Tamar emphasizes the surviving brother's responsibility to "raise up offspring" for the deceased (Gen. 38:8), but likewise is silent on the subject of property and inheritance. $^{53}$ Westbrook argues persuasively that both Genesis 38 and Deuteronomy 25:5 nevertheless do relate to the inheritance of property. ${ }^{54} \mathrm{He}$ also observes that in both texts, the brothers to whom the law applied had lived together in an as yet undivided household. ${ }^{55}$ Likewise, in $R u t h$, the family property may have been, as yet, an undivided inheritance.

In the story of Ruth the property of the deceased Elimelech becomes a central topic in the negotiations of Boaz and the nearest kinsman. Scholarship is divided as to whether levirate marriage is a factor in this book; we shall suggest that it is, without presuming to resolve the issue.

Naomi evidently had inherited Elimelech's land. (Ruth 4:3). She had no surviving sons and was now proposing to sell the property. Elimelech's nearest kinsman (also known as the go'el) evidently had the opportunity, if not also obligation, to "redeem" the land "in order to restore the name of the dead to his inheritance." (Ruth 4:4-6, 10). According to Boaz, the widow of the deceased and the land were a package deal: in order to buy the land, the kinsman would have to

52. Baruch A. Levine, Leviticus, in JPS Torah Commentary 254 (Jewish Pub Soc, 1989); De Vaux, Ancient Israel at 38 (cited in note 7). See particularly Thomas and Dorothy Thompsons' study of "the name," in 18 Vetus Testamentum at 84-88 (cited in note 19).

53. The story of Judah and Tamar does not tell us whether one of the twins inherited (as under the law of primogeniture) or whether both were eligible to do so. Nor is birthright mentioned here. The account of the twins' birth implies that which was born first may have been of some consequence: the midwife carefully ties a scarlet thread around the first hand presented. Deuteronomy 25:6 seems to say that only the "first son" born under levirate marriage would succeed to the name of the deceased. But it is unclear which twin was actually counted as first-born. Both sons were counted as sons of Judah. (Num. 26:19-22). There are no other instances where more than one son was born under levirate marriage.

54. He urges, for example, that Onan hoped to gain his later brother's inheritance by "marrying" Tamar, but avoiding effective intercourse with her, thus leaving no heirs to inherit in his brother's name. Westbrook, Redemption of Land, 6 Israel L Rev at 374-75 n 36 (cited in note 36), Westbrook, The Law of the Biblical Levirate, $24 \mathrm{R}$ Intl des Droits de L'Antiquite 3d Ser at 73 (cited in note 8). Both essays have been reprinted in Westbrook, Property and the Family (cited in note 3 ).

55. Westbrook, Property and the Family at 138, 140-41 (cited in note 3). 
marry the widow ${ }^{56}$ - but Boaz did not specify which widow. (4:5). The next of kin seems to have acknowledged that redeeming the land and marrying "the widow" went together, but declined to exercise his option lest doing so would "impair" his own inheritance. (4:6).

The son (or sons) born to the widow of the deceased under levirate marriage would inherit the property "redeemed" by the kinsman's purchase. ${ }^{57}$ It is unclear; however, how the nearer kinsman would have "spoiled" or "ruined" his inheritance by marrying Ruth. ${ }^{58}$ The kinsman-redeemer would have had to pay a fair price for the property; and he would have had to maintain a wife and perhaps a son. We do not know whether he also would have been obliged to leave to the son by levirate marriage a portion of the estate that otherwise would have passed to any other progeny he may have had. Daube insists that any son by the prospective levirate marriage would have obtained Elimelech's patrimony, but taken nothing "from his physical begetter."59 The NOAB annotator explains that the go'el backed out "because to raise up a son in the name of another would confuse the whole question of the inheritance of the estate." go'el so far had no sons, he might have feared that any levirate son he might have would be his first born, and as such be entitled to the "birthright," which could have included a double share of his estate. That eventuality would have impaired the inheritance of any future sons of his own. Or if the would-be go'el had daughters but no sons he could have feared that a levirate son might inherit his property under customary or statutory law such as Numbers 27, leaving nothing to his daughters. Commenting on Deuteronomy 25:5-10, Patrick suggests, "One reason the brother might not be willing to impregnate his brother's wife is that he and his children are in line for inheriting the deceased man's estate (according to Num. 27:9)."61 However, in

56. See generally Leggett, The Levirate and Goel at 228-45 (cited in note 26). But see D.R.G. Beattie, Kethibh and Qere in Ruth IV 5, 21 Vetus Testamentum 490, 490-94 (1971).

57. See Von Rad, Genesis: $A$ Commentary at 353 (cited in note 15): "The son begotten by the brother is then considered the son and heir of the deceased man, 'that his name may not be blotted out of Israel' (Deut. 25:6)." See also Leggett, Levirate and Goel at 247-48 (cited in note 26).

58. "No passage in this work has produced more headaches." Daube, Ancient Jewish Law at $40-41$ (cited in note 35 ).

59. Id at 40. In Ruth, however, there is no indication that the go'el or nearer kinsman was married or had any children. But see the Thompsons, Legal Problems at 98 (cited in note 19); and Eryl W. Davies, Ruth IV 5 and the Duties of the Go'el, 33 Vetus Testamentum 231, 234 (1983).

60. NOAB at 328 (cited in note 11); cf. NOAB-NRSV at 336 (cited in note 7).

61. Dale Patrick, Old Testament Law 138 (John Knox Press, 1985). But see Westbrook, Redemption of Land, 6 Israel L Rev at 370 (cited in note 36), reprinted in Westbrook, Prop- 
the story of Ruth there is no suggestion that either the go'el or Boaz stood to inherit the property. ${ }^{62}$ Rather, title evidently had passed to Naomi, if not also to Ruth. ${ }^{63}$ Daube's bold and ingenious proposal is that Boaz intentionally misled the nearer kinsman into believing that if he bought the property he would also be obliged to marry the widow Naomi. ${ }^{64}$ They both knew she was too old to have children; if the nearer kinsman married her he risked dying without having heirs, thereby destroying his inheritance. ${ }^{65}$

Levirate marriage, if that is what we find in Ruth, entailed not only the kinsman's duty to perpetuate the name of the deceased, but

erty and the Family (cited in note 3), "If the go'el were also a potential heir, he would frequently be intervening to buy back his inheritance."

62. See Burrows, $59 \mathrm{~J}$ Biblical Lit at 446 (cited in note 36). Under terms of Numbers 27, the kinsman might be expected to have inherited the property. But the text of Ruth insists that Naomi owned the parcel of land. What would have happened to it if she married again? In fact, the kinsman did not inherit it because Boaz redeemed it (by purchase from Naomi) in connection with his marriage to Ruth, and, presumably, Obed eventually inherited it. Thus the kinsman was not in a position simply to assume that he and his children (if any-none are mentioned in Ruth) would inherit from Elimelech. Clearly Naomi's property interest in the parcel had priority over the kinsman's-notwithstanding the provisions of Numbers 27. Exactly what the nature of her interest was, and how she had acquired it, are not, unfortunately, so certain.

63. See above, notes $35-36$ and accompanying text.

64. Daube, Ancient Jewish Law at 40-41 (cited in note 35). Compare Davies, 33 Vetus Testamentum at 231-34 (cited in note 59). Davies suggests that the kinsman understood that he was to marry Naomi and, because she was past child-bearing, expected to acquire her property as his own; but then backed out on learning that the widow in question was Ruth, because she might bear a son who would claim not only the redeemed property but also a share of the go'el's inheritance.

65. Daube, Ancient Jewish Law at 37-43 (cited in note 35). Daube's proposal evidently presumes that Naomi would have been eligible for Levirate marriage even though she had borne sons inasmuch as those sons had died without issue. No other biblical texts present such a situation. His proposal also assumes both that the nearer kinsman had no wife or children at the time, and that monogamy was then the standard societal norm. Because the text does not tell us otherwise, these assumptions are at least plausible. Absent data, interpreters must speculate. Compare Campbell, $R$ uth, in 7 The Anchor Bible at 156 (cited in note 37): "[S]urely [the kinsman] is already married and has a family of his own." Westbrook notes that because Naomi was beyond the age of child-bearing, "the land purchased would pass to the redeemer's sons as part of his inheritance." Westbrook, Redemption, 6 Israel L Rev at 374 (cited in note 36). But that would be a reason for the kinsman to welcome marriage with Naomi! Westbrook reads "widow of the dead" to mean Ruth, and concludes that the kinsman backed out simply because he would have had to pay money for land that would not become part of his patrimony. Id at 374-75. The kinsman's offspring by levirate marriage to Ruth would have inherited the property he had purchased from Naomi. But that outcome would scarcely have "ruined" the kinsman's inheritance (4:6). For another ingenious theory, see Sasson, Ruth: $A$ New Translation with a Philological Commentary at 136-40 (cited in note 36). Sasson suggests that as redeemer, the kinsman could have become liable to support the impoverished Naomi and Ruth's son (if any) who would ultimately inherit the parcel; moreover, under the laws of redemption in Leviticus 25, the kinsman could have had to repurchase the parcel of land as often as these poor relations had occasion to sell it! Sasson denies that levirate marriage is a factor in the story of Ruth. 
also the duty to keep the deceased's property within the ancestral, patriarchal family by redeeming it, i.e., purchasing it from the widow. Otherwise, this land would apparently remain the widow's, at least temporarily, or, if she remarried outside the family, would pass to some other family. ${ }^{66}$ Concern as to the latter outcome is analogous to that expressed in Numbers 36 with respect to heiresses marrying outside the tribe. According to Ruth, the nearest kinsman had first refusal or an option to marry the widow and redeem the property. Under these circumstances, we may see another way the nearest kinsman could have "impaired" his inheritance by marrying Naomi. She was probably past the age of childbearing (1:12-13); if he had no children and predeceased her, as his widow she could have inherited his entire property, or at least a life estate in it.

Another feature of levirate marriage is to be noted in $R$ uth. The story, as told, not only evidences or legitimates extending to the nearest kinsman both the duty of levirate marriage and the duty of redeeming the decedent's property. ${ }^{67}$ The story also, and perhaps more significantly, attests to and legitimates the practice of substituting for a widow who is beyond child-bearing years, her fertile, widowed daughter-in-law when the older widow's sons are now deceased and without heirs. ${ }^{68}$ As Daube rightly points out, the first widow in line for levirate marriage in Ruth is Naomi. ${ }^{69}$ It was, after all, Naomi who programmed Ruth's marriage to Boaz (chap 3). As the story unfolds, Ruth is the biological mother of Obed, the son by levirate marriage, but Obed is hailed as Naomi's go'el (4:14-15), and is presented, in effect, as the surrogate son of Naomi (4:17) and, therefore, implicitly, of Elimelech. ${ }^{70}$

66. See also Beattie, 24 Vetus Testamentum at 251-67 (cited in note 41). Beattie concludes that widows could and did inherit their husbands' property. However, he does not see $R u t h$ chap 4 as instancing levirate marriage. Instead, he sees the scene as "a simple case of the second marriage of a childless widow who has inherited her husband's estate and whose children, by her second marriage, will therefore be heirs, through her, to her first husband." Id at 265 (emphasis added). The kinsman backed off, Beattie suggests, because Boaz had announced his intent to marry Ruth. Under these circumstances, if the kinsman redeemed the property, he would be doing so solely for the benefit of any son(s) born to Boaz and Ruth. Id at 266.

67. See Leggett, The Levirate and Goel at 245 (cited in note 26). It is possible; however, that Deut. 25:5-10 was meant to limit the obligation to the brother-in-law. See also De Vaux, Ancient Israel at 22 (cited in note 7).

68. See also E. Lipinski, Le Mariage de Ruth, 26 Vetus Testamentum 124, 127 (1976). It should not be forgotten that the narrative also implies that the duty of the levirate includes marrying a foreign (or at least a Moabitess) widow.

69. Daube, Ancient Jewish Law (cited in note 35). See Ruth 1:12, where Naomi speaks, albeit hypothetically, of having a husband, presumably a kinsman of Elimelech, and having sons whom the younger widows could marry, if they waited long enough.

70. Compare Westbrook, The Law of the Biblical Levirate, $24 \mathbf{R}$ Intl des Droits de 


\section{Redemption, Jubilee Laws, and Inheritance}

The idea that kinsmen have an obligation to "redeem" property in order to keep the inheritance in the family also appears prominently along with the laws pertaining to the Jubilee year. ${ }^{71}$ The main legal provisions are set out in Leviticus 25 . Here, however, the underlying concern is not preserving tribal inheritances, but rather preserving the land inheritances of each Israelite family or clan. To implement this policy, the Jubilee laws provided that farmland might not be sold "in perpetuity," or rather, "not beyond reclaim." 72 The theological premise is the understanding that the land ultimately belonged to Yahweh, and that his people were only "strangers and guests." (Lev. 25:23). ${ }^{73}$ Thus land, at any rate farmland, was not a commodity to be bought and sold. ${ }^{74}$

Under the Jubilee laws, Israelites might, in effect, lease or rent their farmland to others. ${ }^{75}$ They not only could re-take possession of it every fiftieth year but were obliged to do so: "In this year of jubilee each of you shall return to his property." who owned the land earlier had died, his heir or heirs would retake possession on his behalf. (It seems unlikely that the drafters of the Jubilee year law expected all property owners to live another fifty years, let alone, forever.) Although deeds for land sales were signed and witnessed, so far as we know, there was no provision for recording property transactions (cf. Jer. 32:11-14); returning to the land evidently had the effect of re-asserting the property owner's title to it. After so returning, the owner presumably could "sell" or lease it again, either to the same lessee or to some one else for the next forty-

L'Antiquite, 3d Ser at 77 n 43 (cited in note 8), reprinted in Westbrook, Property and the Family (cited in note 3). Here he asserts that "Boaz does not raise up Elimelech's name . . only Mahlon's." It is not clear, however, that "the dead" $(4: 5,10)$ alludes to Mahlon rather than Elimelech.

71. See generally, David Daube, Studies in Biblical Law 43-45 (KTAV, 1969); Westbrook, Jubilee Laws, 6 Israel L Rev 209 (1971), reprinted in Westbrook, Property and the Family (cited in note 3 ).

72. See Levine, Leviticus, in JPS Torah Commentary at 270-74 (cited in note 52). Houses within a walled city, however, could be sold in perpetuity (Lev. 25:29-30) unless the cities in question were "cities of the Levites." (Lev. 25:32-33). But houses within unwalled villages, like farmland, could not be sold in perpetuity. (Lev. 25:31). Property not subject to sale in perpetuity supposedly would revert to its original owner in the Jubilee year.

73. See generally, John Hart, The Spirit of the Earth, A Theology of the Land 69-71 (Paulist Press, 1984) (translation suggested by Hart).

74. Westbrook, Redemption of Land, 6 Israel L Rev at 367-68 (cited in note 36), reprinted in Westbrook, Property and the Family (cited in note 3).

75. Westbrook, Jubilee Laws, 6 Israel L Rev at 221 (cited in note 71); Levine, Leviticus at 173, 273 (cited in note 52).

76. Lev. 25:13; see also Lev. 25:10, 28. 
nine years. Land "sales" or leases could be entered into at any time within the forty-nine year cycle, but the "price" or rent was to take into account the number of years-specifically, the number of annual crops-since the last Jubilee year. (Lev. 25:15-16).

If a man became poor and had to "sell" (or lease) part of his property, his brother or next-of-kin was obliged to "redeem" what had been sold, evidently lest it pass out of the family in the interval before the next Jubilee year. ${ }^{77}$ But if there was no one to redeem it, and the owner himself could not afford to buy it back in the meantime, the land would, nevertheless, revert to the owner (or, presumably, his heirs) in the year of Jubilee. (25:25-28).

Curiously, none of the redemption or Jubilee laws in Leviticus 25 refers expressly to the inheritance of land. It is often noted that there is no evidence that the Jubilee year law provisions were ever carried out. Unlike levirate marriage, Jubilee laws do not even appear in the background of any biblical narrative except, perhaps, $R$ uth. But some other texts do take cognizance of the Jubilee year, and some of these texts explicitly relate it to the matter of inheritance.

Various laws in Leviticus 27:16-25, 28 distinguish between land a person possessed by inheritance and land one has "bought, which is not a part of his possession by inheritance." (27:22). A man may "redeem" (or repurchase) inherited land which he has vowed or pledged to Yahweh any time up to the year of Jubilee. ${ }^{78}$ But if he failed to redeem it by the year of Jubilee, it would not revert to him, but instead would become "holy to Yahweh"79 and "the priest"80 would take possession of it. But if a man dedicated a field which he had bought (or leased) which was not his by inheritance, such land would not become "holy to Yahweh" in the Jubilee year. Instead, "[i]n the

77. Westbrook urges that the right of redemption arose only when the seller had become impoverished and sold to a third party at less than normal price. See generally, Westbrook, Redemption, 6 Israel L Rev at 368 (cited in note 36); and Westbrook, The Price Factor in the Redemption of Land, 32 R Intl des Droits de L'Antiquite, 3d Ser at 97 (cited in note 3). Both essays are reprinted in Westbrook, Property and the Family (cited in note 3).

78. A man who redeemed such land was to add a fifth of its value to the redemption price. (Lev. 27:19).

79. Leviticus 27:20-21 also provides that inherited land which a man has "sold" or leased to someone else, if not redeemed in the meantime, likewise would become holy to Yahweh in the Jubilee year. The Lessee's (or lease-holder's) interest would not be affected however, because the lessor (or original owner) otherwise would have retaken possession in the Jubilee year, thereby extinguishing the lessee's interest anyway.

80. Presumably "the priest" referred to throughout Leviticus 27 is the priest who happened to handle the particular case on behalf of the Jerusalem hierarchy. Similarly, modern lawyers refer, for example, to "the magistrate" or "the judge," meaning the one who happens to hear a particular case. 
year of jubilee the field shall return to him from whom it was bought, to whom the land belongs as a possession by inheritance." (27:24). In other words, a man could not dedicate to Yahweh land that was not his by inheritance but belonged to some one else. Only the owner of inherited land could dedicate it to Yahweh. ${ }^{81}$

Numbers 36:1-4 provides another footnote to the situation of the famous daughters of Zelophehad, this time in connection with the year of Jubilee. Here we see what might have happened if Moses (or Yahweh) had not provided that heiresses marry only within their ancestral tribe. Absent such provision, the text implies, if these heiresses had married husbands from other tribes, their land would have been transferred permanently to their husbands' tribes in the year of Jubilee (36:3-4). It is unclear, however, how or why the Jubilee law as we know it from Leviticus 25 would have required that result or even been relevant to the situation. ${ }^{82}$

A final series of laws of inheritance relating to the Jubilee year appears in Ezekiel 46:16-18, in the curious context of "ordinances" or "laws" of the temple revealed not to Moses, but to Ezekiel. (44:546:18). These laws concern the power of "the prince" to distribute property from inheritances-a subject strangely unrelated to temple ordinances or laws. "The prince" may represent the King who was expected to rule Israel righteously in the ideal world after the exile or in the messianic age, ${ }^{83}$ or, perhaps, stand for post-exilic officials who might have been tempted to exploit their subjects. ${ }^{84}$ These laws contain two main provisions. The first allows "the prince" to make gifts or bequests out of his own inheritance to his sons, because the sons would eventually take by inheritance anyway. But any gifts the prince gives to his servants from his inheritance are to revert to the

81. Leviticus $27: 28$ provides that when a man has "devoted" an inherited field to Yahweh, it shall neither be sold nor redeemed. Perhaps "devoted" property is that which has already been given to Yahweh. Presumably a field so "devoted" would not be destroyed, unlike the fate of man and beast "devoted" under the old herem tradition. See Joshua 6:17, 21; Lev. 27:29. Perhaps "the priest" would take possession of the devoted field as in the case of dedicated land released in the Jubilee year. (Lev. 27:16-21).

82. If husbands were entitled to heiresses' inheritances as suggested in the book of Tobit (Tobit 6:11-12 and 14:13), such inheritances would pass out of the tribe if the husbands belonged to other tribes apart from the operation of the law of the Jubilee year. See Num. 36:3. Westbrook suggests that Num. 36:4 may have been a "mistaken gloss." Westbrook, Jubilee Laws, 6 Israel L Rev at 210 (cited in note 71), reprinted in Westbrook, Property and the Family at 36 (cited in note 3). Compare Norman H. Snaith, The Daughters of Zelophehad, 16 Vetus Testamentum 124, 127 (1966).

83. See Ezek. 45:7-9; cf Isaiah 11:1-9.

84. For example, the "officials and nobles" against whom Nehemiah contended and some of the earlier post-exilic governors characterized in Neh. 5:1-15. 
prince (or, presumably, his heirs) in "the year of liberty." (Ezek. 46:16-17). "Gifts" may include not only real property, but any kind of property subject to inheritance. The second provision bars the prince from taking the inheritances of others:

The prince shall not take any of the inheritance of the people, thrusting them out of their property; he shall give his sons their inheritance out of his own property, so that none of my people shall be dispossessed of his property. (Ezek. 46:18.)

Here the peoples' inheritance appears to designate their land or real property-from which they might otherwise be "thrust out" by an unduly acquisitive prince or king. Perhaps this law was added in Ezekiel precisely because the Mosaic law contained no provision forbidding such conduct. ${ }^{85}$ Earlier kings and others in positions of power had not always respected the inheritances of their subjects. ${ }^{86}$ Ezekiel (or a later editor) evidently wished to make sure that subsequent rulers, including, perhaps, early post-exilic functionaries, would know that they were not to expropriate their subjects' inheritances.

\section{The Birthright}

The elusive biblical "birthright" tradition resembles intestate succession in that it seems to have affected inheritance from one generation to another by operation of law. Less is known about the biblical birthright than annotators and commentators sometimes pretend. Harper's Bible Dictionary, for example, states flatly: "Biblical legislation ... established the right of the firstborn to inherit a double portion of his father's possessions, i.e., twice as much as that received by each of his brothers." 87 The commentator cites as authority the locus

85. See, however, the prohibition against coveting one's neighbor's house in Exodus 20:17 and Deut. 5:21, and the prohibition against coveting his field in the latter text. Westbrook notes that because of dating problems, we do not know "whether Ezekiel was inspired by Leviticus, or Leviticus by Ezekiel," or both by a common ideal. Jubilee Laws, 6 Israel L Rev at 226 (cited in note 71 ).

86. 1 Kings 21:1-16; Isaiah 5:8; Micah 2:1-2. See generally, B. Davie Napier, The Inheritance and the Problem of Adjacency: An Essay on 1 Kings 21, 30 Interpretation J Bible \& Theology 3-11 (1976). Weingreen argues persuasively that the Naboth story in 1 Kings 21 , and also Num. 27:3-4, evidence the existence and operation of a law whereby property that otherwise would pass to heirs was confiscated by the sovereign if the owner had committed treason. Weingreen, 16 Vetus Testamentum at 521-22 (cited in note 10). Compare the Parable of the Wicked Tenants, Matt. 21:33-39 = Mark 12:1-8 = Luke 20:9-15, where the tenants try to obtain the heir's "inheritance" by killing the heir. In contrast, King Omri purchased his estate, possibly from a kinsman (1 Kings 16:24). See Lawrence E. Stager, Shemer's Estate, 277/ 278 Bull Am Sch Oriental Research 93, 103-04 (1990).

87. $H B D$ at 421-22 (cited in note 16). Strangely, many commentators assume that Deut. 21:15-17 requires that the older or oldest son receive a double share of the inheritance where there is no question as to a loved and unloved wife. See, for example, James Kent, in John M. 
classicus, Deuteronomy 21:15-17. But this text refers only to what must be done in the following special situation:

If a man has two wives, the one loved and the other disliked, and they have borne him children, both the loved and the disliked, and if the first-born son is hers that is disliked, then on the day when he assigns his possessions as an inheritance to his sons, he may not treat the son of the loved as the first-born in preference to the son of the disliked, who is the first-born, but he shall acknowledge the first-born, the son of the disliked, by giving him a double portion of all that he has, for he is the first issue of his strength; and the right of the first-born is his. (Deut. 21:15-17).

There is no biblical legislation establishing the rights of the firstborn. ${ }^{88}$ The law of intestate succession in Numbers 27 is entirely silent as to any special entitlements on the part of first-born sons or daughters. To be sure, it can plausibly be inferred from Deuteronomy 21:15-17 that as a matter of unwritten custom or tradition at some time or another, the first-born son ordinarily may have received a double portion. ${ }^{89}$ It is odd that there are no other biblical texts that illustrate or follow such a tradition. We shall examine shortly those texts that may, nevertheless, pertain to inheritance by birthright.

One other feature of the law of Deuteronomy 21:15-17 is to be noted first. Verse 16 refers to the day on which a man "assigns his

Gould, ed, Commentaries on American Law 376-77 (Little Brown, 14th ed, 1896); James G. Frazer, Folk-lore in the Old Testament $430 \mathrm{n} 1$ (Macmillan, 1919); C.J. Mullo Weir, Nuzi, in D. Winton Thomas, ed, Archaeology and Old Testament Study 76 (Clarendon, 1967); Richardson, ed, Theological Word Book of the Bible at 83 (cited in note 1); NWDB at 376 (cited in note 16); Baab, $2 I D B$ at 702 (cited in note 16). Compare Westbrook, Property and the Family at 20 (cited in note 3): "The law (Deut. 21:15-17) renders invalid the father's gift in these special circumstances, where his preference is based on his attitude to his wives, not to the children themselves. By the same token, the right to reallocate the traditional shares among the heirs in other circumstances is acknowledged, and indeed adopted as normal practice."

88. Nuzi evidence is ambiguous. Nashwi's will (or "tablet of adoption") provided that his adopted son, Wullu, would share his estate equally with any of Nashwi's own sons. Zike's will (or tablet of adoption) provided that a certain Shuriha-ilu would take a double share if he (Shuriha-ilu) had a son of his own. Pritchard, ed, $A N E T$ at 219-20 (cited in note 16). These texts illustrate ancient wills, but do not appear relevant as to inheritance or birthright.

The only ancient Near Eastern texts apparently providing that the oldest son take two portions of inherited land are Middle Assyrian Laws, tablet B, id at 185, and an old Babylonian (Mari) judicial decision. Pritchard, ed, $A N E$ at 545 (cited in note 48).

89. See also Patrick, Old Testament Law at 129 (cited in note 61): "The ruling assumes the principle of primogeniture-that a man's firstborn male child receives a double portion of his inheritance." But see below, note 105 and accompanying text. See generally, Eryl W. Davies, The Meaning of pi senayim in Deuteronomy XXI 17, 36 Vetus Testamentum 341, 34145 (1986). Calum M. Carmichael suggests that the double portion provision in Deut. 21:15-17 may represent merely "the lawgiver's interpretation of what Jacob had done for Joseph in settling the prime inheritance upon him" in Gen. 48 and 49. Uncovering a Major Source of Mosaic Law: the Evidence of Deut. 21:15-22:5, $101 \mathrm{~J}$ Biblical Lit 505, 506-08 (1984). 
possessions as an inheritance to his sons." This verse suggests a process very much like testation, the making of a will. What Deuteronomy 21:15-17 says, in effect, is that a man may not ignore his obligation to provide his first-born son with a double portion just because he dislikes that son's mother. Thus, this law is somewhat similar in purpose to modern statutes that prevent one spouse from "writing" or "cutting" the other "out of" his or her will by providing that the survivor may elect a "spousal share" in lieu of taking under terms of the will. ${ }^{90}$

The idea that a first-born son might be entitled to a larger share of his father's inheritance is supported by the ancient Hittite story of Appu and his twin sons. ${ }^{91}$ After Appu and his wife die, the twins set out to divide up the family property. The older justifies helping himself to the "sleekest cow" by arguing, "Am I not the elder? And what says the law? 'The larger portion to the eldest, the smaller to the others." "92 The extant portions of Hittite law codes, however, do not refer to inheritance, ${ }^{93}$ but it may well be that the biblical birthright tradition was influenced by earlier Hittite or other ancient Near Eastern law or custom. ${ }^{94}$

It is remarkable; however, that no other biblical traditions indicate that the first born son had the right to a double or even enlarged portion of the inheritance. ${ }^{95}$ The law of intestate succession in Numbers 27 makes no reference to double portions. Nevertheless, annotators typically assume or assert that the birthright Jacob purchased (or extorted) from brother Esau consisted of "a double share of the inher-

90. Similarly, under Islamic law, a man could not disinherit his wife-or anyone else. All was spelled out. See above, note 12 .

91. Theodor H. Gaster, The Oldest Stories in the World 159-71 (Beacon Press, 1958).

92. Id at 163; see also id at 164: "The law says clearly that the eldest is to have the most." "

93. Id at 169.

94. The $H B D$ reports that several other ancient Near Eastern cultures provided for "preferential treatment of the eldest son," but that the codes of Lipit-Ishtar and Hammurabi required that all male heirs inherit equal shares. $H B D$ at 134-35 (cited in note 16). See LipitIshtar Law Code $\S 24$, in $A N E T$ at 160 (cited in note 16); Code of Hammurabi $\S 170$, in Thomas, ed, Documents from Old Testament Times at 33 (quoted above in note 14). The Babylonian Theodicy, vv. 245-64, however, suggests that the first-born may have enjoyed special favor or status. Thomas, Documents at 101. See generally, Isaac Mendelsohn, On the Preferential Status of the Eldest Son, 156 Bull Am Sch Oriental Research 38-40 (1959).

95. Arguably, Jacob gave Joseph a double share by adopting or otherwise designating the latter's two sons as recipients of equal shares with Joseph's brothers. (Gen. 48:1-6). Nothing is said here; however, about birthright or transfer of birthright. The arrangement is more in the nature of a bequest. See below, text accompanying note 112. It may well be, however, that this scene was meant to explain how it came about that Ephraim and Manasseh enjoyed full tribal status, and provides no information as to transfer of property by inheritance or bequest. 
itance."96 The biblical account of that transaction, Genesis 25:29-34, however, gives no clue at all as to the substantive content of a birthright. ${ }^{97}$ The story does demonstrate that whatever benefits the birthright afforded, it was considered alienable, that is, it could be sold, at least between sons prior to the father's demise. ${ }^{98}$ It is possible that birthright tradition may be part of the background in the story in Genesis 21:8-14, where Sarah calls on Abraham to "cast out" Hagar and Ishmael. Ishmael was Abraham's first born son. In effect, Abraham here disinherited him. Whether the birthright entailed a double portion of the estate or leadership of the clan, Sarah no doubt would have wished to reserve such benefits for her son, Isaac.

If we may credit the Chronicler on this point, Reuben forfeited his birthright because he had engaged in sexual relations with his father's concubine or wife, Bilhah. ${ }^{99}$ Forfeiture of Reuben's birthright, however, is not explicitly reported in Genesis traditions. ${ }^{100}$ In Chronicles, the chief consequence of this forfeiture was that Reuben was "not enrolled in the genealogy according to his birthright." (1 Chron. 5:1). So we find no further evidence here as to whether birthright meant a

96. For example, $N O A B$ at 31 (cited in note 11 ); NOAB-NRSV at 32 (cited in note 7); $N E B 26$ (cited in note 16). Unaccountably, a page earlier, the $N E B$ annotator asserts that the first-born "had exclusive rights of inheritance." Id at 25 . Other than in the situation of Levirate marriage (Deut. 25:6), no biblical text suggests that the first-born son alone inherited when there were other sons. Frazer makes a plausible case for the idea that traces of ultimogeniture, or inheritance by the youngest son, can be found in biblical tradition. Frazer, Folk-Lore in the Old Testament at 429-33 (cited in note 87). Aside from Gen. 25:29-34, however, none of the texts he discusses involves inheritance of property. In Gen. 25:29-34, it is clearly implied that the older son normally would have enjoyed the birthright.

97. See Von Rad, Genesis: $A$ Commentary at 262 (cited in note 15): "[W]hat is to be understood by the birthright is not sufficiently clear from the narrative."

98. See also $H B D$ at 135 (cited in note 16). See generally, Reuben Ahroni, Why Did Esau Spurn the Birthright? 29 Judaism 323-31 (1980). The NOAB annotator inexplicably cites Gen. 25:29-34 as authority for the proposition, "In antiquity it was believed that the right of the first-born was inalienable." $N O A B$ at 242 (cited in note 11); $N O A B-N R S V$ at 245 (cited in note 7).

99. 1 Chron. 5:1. In Gen. 30:4-8 Bilhah is characterized as Jacob's wife and as the mother of Reuben's brothers, Dan and Naphtali. In Gen. 35:22 Bilhah is said to have been Jacob's concubine.

100. See Gen. 35:22 and 49:3-4. The latter text reports that Jacob declared that Reuben would lose his "pre-eminence." Westbrook suggests that such pre-eminence of preference included "the right to administer the paternal estate while still undivided, which would normally have been assigned to the first-born." Westbrook, Property and Family at 136 (cited in note 3). Pre-eminence is also associated with birthright or the status of the first-born in Gen. 27:36-37 and 43:33. On the significance of Reuben's offense, see Judah Goldin, The Youngest Son or Where Does Genesis 38 Belong, 96 J Biblical Lit 27, 37-38 (1977). Goldin concludes that Reuben thereby intended to proclaim that he had succeeded his father, just as Absalom later did when he publicly took over his father's concubines (See 2 Samuel 16:20-22). 
double or enlarged inheritance. ${ }^{101}$

Conceivably, birthright tradition forms part of the background for the incident described in Luke 12:13: "One of the multitude said to [Jesus], 'Teacher, bid my brother divide the inheritance with me." " Our diligent $N O A B$ annotator could not refrain from adding a footnote citing Deuteronomy 21:17 for the proposition that "the elder received double the younger's share."102 There is no hint in the Lucan text, however, that the older brother was claiming a double portion. Nor is there any reference to birthright here, so we have no reason to believe that birthright was an issue in the dispute between the brothers. Again, the birthright tradition may be implicated in the Parable of the Prodigal Son. (Luke 15:11-32). The younger son asked his father to give him "the share of property" he would otherwise eventually inherit. The parable then says that the father "divided his living between them." (15:12). Here, too, however, there is no mention of birthright nor is there any indication that the older brother claimed or was entitled to a double portion. The parable does suggest that a son might ask for an advance on his eventual anticipated inheritance, but whether this concept reflects actual practice or custom within the biblical period we cannot say. It may only be a fictive element within the parable.

In summary, the notion that the biblical birthright meant that the older or oldest son was entitled to a double portion of his father's inheritance depends entirely upon Deuteronomy 21:15-17. That text does not use the expression "birthright," nor does it require that the older son receive a double portion of the inheritance under circumstances other than the peculiar one where the father loves one wife and dislikes the other. ${ }^{103}$ No other biblical text intimates that the first-born son was entitled to a double share of his father's inheritance. ${ }^{104}$ Nor is there any indication that primogeniture was prac-

101. See generally, Stanley Gervitz, The Reprimand of Reuben, $30 \mathrm{~J}$ Near E Studies 87, 8798 (1971).

102. $N O A B$ at 1263-64 (cited in note 11); NOAB-NRSV at 101 NT (cited in note 7).

103. Here again, it may be that biblical customary law derived from other Near Eastern cuneiform law. To what extent the latter required that the first-born son receive a double portion, however, is uncertain. See above, notes 87-94 and accompanying text.

104. Another aspect of birthright tradition or custom may be better attested, namely, the oldest brother's seniority and leadership status within the family. See for example, Gen. 43:33, 1 Chron. 26:10, 2 Chron. 21:3, and discussion of these and several other texts in Gordon, $54 \mathrm{~J}$ Biblical Lit at 223-31 (cited in note 6). Because we are concerned only with inheritance of property, this aspect of biblical birthright tradition is not examined further here. See above note 100 . 
ticed in biblical times. ${ }^{105}$

\section{WILLS OR BEQUESTS AND INTER-VIVOS GIFTS}

What distinguishes bequests or gifts from inheritance through intestate succession is that the former require some affirmative act by the testator or donor in order to make the gift effective. Necessarily, such act can be taken only during the lifetime of the testator or donor.

No biblical text indicates that anyone in the biblical community ever drafted and signed a testamentary instrument or authorized an executor to transfer property to beneficiaries upon the testator's demise. In his classic study of ancient law, Henry Sumner Maine asserted that biblical Israelites or Jews had not developed the institution of testation. ${ }^{106}$ There are no laws governing testamentary succession in the Bible. ${ }^{107}$ Nevertheless, several texts do suggest that people in the biblical period occasionally did make some kind of testamentary disposition of their property. Sometimes this disposition was made shortly before the testator's death, apparently in the form of an oral deathbed will. In other instances, such gifts appear to have been made prior to the donor's imminent expectation of death. Some of these gifts, though arguably testamentary in character, could also be described as inter-vivos gifts, that is, as gratuitous transfers of property between living persons.

105. But see above, note 96 regarding Deut. 25:6. Henry Sumner Maine insisted, properly, that birthright should not be confused with primogeniture. He defined the latter as "the exclusive succession of a single son" to his father's property. Lectures on the Early History of Institutions 197 (London, 7th ed, 1905). Nevertheless, interpreters occasionally use the terms "primogeniture" and "birthright" interchangeably. For example, Ahroni, 29 Judaism at 32325 (cited in note 98). Without citing supporting evidence, De Vaux asserts, "It is probable that when land was inherited it was not shared like other property but passed to the eldest son or remained undivided." De Vaux, Ancient Israel at 166 (cited in note 7).

106. Henry Sumner Maine, Ancient Law 209 (Wm S Hein Co, 10th ed reprint, 1983). See also Emanuel Rackman, A Jewish Philosophy of Property: Rabbinic Insights on Intestate Succession, 67 Jewish Q Rev 65, 65-89 (1976). But see Isaac Herzog, 1 The Main Institutions of Jewish Law 296-98 (Socino Press, 1965). Maine, of course, would not have known the vast body of recently recovered, ancient Near Eastern materials which show that the institution of testation was well established in many of these cultures. See generally, Szubin and Porten, 252 Bull Am Sch Oriental Research at 35.46 (cited in note 1). For particular instances, see below notes $110,111,120$, and 122 .

107. Solomon Zeitlin, Testamentary Succession: A Study in Tannaitic Jurisprudence, in Abraham A. Neuman and Solomon Zeitlin, eds, Seventy-Fifth Anniversary Volume of the Jewish $Q$ Rev 574 (Jewish Q Rev, 1967). See also translation of Deut. 21:16 in NOAB-NRSV at 245 (cited in note 7): "on the day when he wills his possessions to his sons . ..." 


\section{A. Gifts or Bequests in Prospect of the Testator's or Donor's Death}

Deuteronomy 21:15-16 refers to "the day when [a man] assigns his possessions as an inheritance to his sons." We may infer that this assignment was equivalent to a person's "putting his affairs in order," and more specifically, determining what property would go to which son. ${ }^{108}$ This assignment need not necessarily have taken place in imminent anticipation of pending demise. It is likely that Genesis 24:36 and 25:5-6 reflect this kind of testamentary practice. In both texts it is said that Abraham gave Isaac all that he had. ${ }^{109}$ The latter adds that Abraham also had given gifts to the sons of his concubines. Here the "bequest" is referred to as if it already had been conveyed to the beneficiaries. ${ }^{110}$ Technically, most if not all of the biblical "bequests" were inter-vivos gifts. But because most of these conveyances occurred while the donor was in advanced years in order to pass property to heirs, these gifts can be said to have functioned as bequests.

We see something very similar to a deathbed will in Genesis 48:21-22. After stating that he is about to die, Jacob tells Joseph, "I have given to you rather than to your brothers one mountain slope which I took from the hand of the Amorites with my sword and with my bow."111 Jacob's adoption of Joseph's two sons, implicitly granting each an inheritance, in Genesis 48:1-6, likewise appears to be a bequest made in anticipation of the testator's death. ${ }^{112}$ Similarly, 2 Chronicles 21:2-3 reports that King Jehoshaphat gave his sons "great gifts, of silver, gold, and valuable possessions, together with fortified cities in Judah," evidently just before his death. ${ }^{113}$ Sirach 33:23 spe-

108. See above note 87 and accompanying text. De Vaux suggests that 2 Samuel 17:23 and 2 Kings 20:1 refer to situations where "a father . . gave verbal instructions about the distribution of his property." Ancient Israel at 53 (cited in note 7).

109. Presumably this estate included, inter al., the cave of Machpelah. See Westbrook, Purchase of the Cave of Machpelah, 6 Israel L Rev at 29-38 (cited in note 3), reprinted in Westbrook, Property and the Family at 24 (cited in note 3).

110. See Thomas E. Atkinson, The Law of Wills 7 n 11 (West, 2d ed, 1953). Atkinson observes that Sennacherib's will, executed ca. 681 B.C.E., likewise used the formula, "I have given" rather than "I give."

111. See also a quotation from a Nuzi text deathbed will whereby a dying father gives a female slave to one of his sons as his wife. C.J. Mullo Weir, Nuzi, in Thomas, ed, Archaeology and Old Testament Study at 76 (cited in note 87).

112. See Szubin and Porten, 252 Bull Am Sch Oriental Research at 37 (cited in note 1) But see above, note 95 .

113. Because the Chronicler reports Jehoshaphat's death and burial before stating that he gave his sons these gifts, it might be supposed that the sons received these gifts through a testamentary instrument or will. (2 Chron. 21:1-3). But it is equally likely that the Chronicler merely meant to say that Jehoshaphat had given his sons these gifts prior to his death. 
cifically commends the practice of deathbed distribution: "At the time when you end the days of your life, in the hour of death, distribute your inheritance."114 Related texts caution against making earlier inter-vivos gifts: "[D]o not give your property to another, lest you change your mind and must ask for it [back]." (Sirach 33:19-21).

A few testamentary gifts or bequests are described in the pseudepigraphic literature. ${ }^{115}$ Jubilees 45:14-15 says that Jacob (Israel) "gave to Joseph a double portion upon the land" (cf. Gen. 48:5-6), and gave all his books and his father's books to his son Levi, to pass on, in turn, to his sons. In the Testament of Job, that ancient worthy tells his children that he is dying, and proceeds to distribute his estate or "goods" to his seven sons, except for three magical "sashes" or phylacteries, which he gives, one each, to his three daughters. (Testament of Job 45:1-50:3). Responding to the daughters' complaint that these were of little value, Job characterizes the sashes as "an inheritance better than that of your seven brothers." (Testament Job 46:4). ${ }^{116}$

\section{B. Inter-vivos Gifts to Eventual Heirs}

Although as the biblical story is told, Job was an Edomite, not an Israelite or Jew, it is arguable that the beliefs and practices attributed to him and others in the book are more representative of biblical than of Edomite tradition. ${ }^{117}$ Job 42:15-16 tells that Job gave inheritances to both his sons and daughters, and then lived 140 years. It is unclear whether the story-teller meant to say that Job transferred all his property to his children 140 years before his death, or that he gave some property to them, retaining what he would need for his own purposes, or that he made a testamentary disposition to the effect that they would receive their inheritances after his death. The last possibility is the least likely, because it is unreasonable to suppose that the reader would expect Job's children to have survived him. ${ }^{118}$

114. De Vaux reads Sirach 14:13 similarly. Ancient Israel at 53 (cited in note 7).

115. The following citations are all drawn from James $\mathrm{H}$. Charlesworth, ed, The Old Testament Pseudepigrapha, 2 vols (Doubleday, 1983, 1985).

116. See also Joseph and Aseneth 29:9(11), in Charlesworth, 2 The Old Testament Pseudepigrapha (cited in note 115), which tells that after reigning as king in Egypt for forty-eight years, Joseph "gave the diadem" to Pharaoh's young son.

117. See, for example, the orthodox wisdom theology represented by Job's friends, the creation faith endorsed in Job 38-39, and Job's exemplification of the covenant ethic in 29:11-17; 31:1-40. Dating and authorship of $J o b$ are uncertain, but its congruence with both certain biblical and cuneiform traditions is beyond doubt. See Marvin H. Pope, Job, in The Anchor Bible XXXII-XLII (Doubleday, 3d ed, 1973).

118. If Job had arranged to leave his property to his children upon his death, and then 
The former possibilities are paralleled to some extent in the Parable of the Prodigal Son. (Luke 15:11-32). There, the father gives the younger son in advance the share of the inheritance he otherwise would receive at the father's death. After this son returns from his fling at riotous living, the older brother points out that his profligate brother had "devoured" their father's property. ${ }^{119}$ That point, of course, is no problem to the prodigal's father, who eagerly welcomes him back. Yet unless at the time he advanced the prodigal his inheritance the father retained a portion of his estate for his own use, the father (and also the prodigal) would now have to live on the estate previously earmarked as the older brother's inheritance. (Cf. Sirach 33:19-23). Whether Job transferred all his property to his children and then was supported by them, or retained some to provide for his own support, we cannot tell. That detail was not of interest to the narrator.

Testamentary arrangements are also noted in the story of Judith. Though her husband died unexpectedly (8:2-3), he "had left (hupelipeto) her gold and silver, and men and women slaves, and cattle, and fields." (8:7). It appears that Judith's husband had made some provision to transfer his estate to her either before he was taken ill or in the interval before he died. He had other relatives (16:24) who otherwise, perhaps, would have inherited under the law of intestate succession. (Num. 27:8-11). ${ }^{120}$ Then, at the end of the story, before she died, she distributed her property to various relatives. (Judith 16:24). Clearly her intent was to bequeath the estate to certain devisees or beneficiaries. Thus, not only men, but also women could devise property by will or bequest.

lived another 140 years, his children would have taken nothing unless they managed to out-live him. Job was the only biblical person since the days of the "patriarchs" (Gen. 25:7; 35:28) said to have lived as long as 140 years, let alone longer. Pope notes that the Septuagint credits Job with a total of 240 years. Pope, Job at 353-54 (cited in note 117).

119. "[T] his son of yours ... has devoured your living with harlots." Luke 15:30. See also Luke 15:13. Earlier wisdom traditions had warned against such conduct. See Sirach 9:6: "Do not give yourself to harlots lest you lose your inheritance."

120. There are other instances; however, where biblical widows apparently inherited their husbands' real property notwithstanding the written law of intestate succession in Numbers 27 . See above, text accompanying notes 35-46. The bequest to Judith parallels a Ugaritic oral will in which a certain Yarimanu bequeathed his entire estate-including animals, slaves, bronze bowls, kettle and jugs, baskets, and a field-to his wife. That will, however, went on to provide that the couple's sons would be penalized if they sued their mother for the estate, but that she was to bequeath the estate to whichever son paid her respect. Pritchard, ed, $A N E$ at 546 (cited in note 48). 


\section{Eligible Devisees or Beneficiaries}

To whom might property be bequeathed? Were there any eligibility requirements? What we have called the law of intestate succession in Numbers 27 evidently did not limit testators who wished to dispose of their property otherwise. ${ }^{121}$ To be sure, sons were likely to be the sole devisees or beneficiaries. Gifts might also be given to the sons of concubines. (Gen. 25:5-6). Job gave or bequeathed an inheritance not only to each of his seven sons, but also to each of his three daughters. ${ }^{122}$ Presumably the daughters were given shares equal to those given their brothers. ${ }^{123}$ Proverbs 13:22 says, "A good man leaves an inheritance to his children's children." This proverb could mean leaving a bequest for granddaughters as well as grandsons. ${ }^{124}$ Numbers 27, it will be recalled, made no provision for grandchildren. Nor did it provide for wives, but that did not prevent Judith's husband from leaving her his estate. (Judith 8:7; 16:21). That a man might bequeath property to his widow was well-established in Ugaritic law, ${ }^{125}$ at Nuzi, ${ }^{126}$ and in the Code of Hammurabi $\S 150 .{ }^{127}$ It is not necessary to suppose that Israelites or Jews adopted such practices only in the late biblical period.

The Judith story also introduces another variation on Numbers 27. Before Judith died, in anticipation of death, she distributed her estate not only to her husband's next of kin, but also to her own. (Judith 16:24). Neither of these kinds of distribution was provided for in Numbers 27 which, in the first place, only governed transfer of

121. See H.H. Rowley, Job, in Ronald E. Clements and Matthew Black, eds, New Century Bible 268 (Attic Press, 1985).

122. An Old Babylonian text records that a woman bequeathed real property to her adopted daughter. $A N E$ at 543-44 (cited in note 48). Several instances of bequests to daughters are found among the 5th century B.C.E. Aramaic legal documents from Elephantine. See Szubin and Porten, 252 Bull Am Sch Oriental Research at 41-44 (cited in note 1). Daughters were beneficiaries of bequests in ancient Elam as well. See Ben-Barak, $25 \mathrm{~J}$ Semitic Studies at 31-32 (cited in note 27). Cf Joshua 15:14-19, Judges 1:11-15 (inter-vivos gift to daughter).

123. See A. van Selms, Job 158 (Eerdmans, 1985). But see Zafrira Ben-Barak, Job's Daughters and the Question of Inheritance in Israel and the Ancient Near East, in Society of Biblical Literature 1990 Intl Meeting Abstracts 7-8: "The daughters are given part of the inheritance, albeit in an inferior way." This issue evidently troubled an earlier interpreter. See above, text accompanying note 116 .

124. Grandchildren were also named as beneficiaries at Elephantine. Szubin and Porten, 252 Bull Am Sch Oriental Research at 41-44 (cited in note 1). However, Proverbs 13:22 could mean only that a righteous man's wealth would be enjoyed by his intestate heirs to the third generation. Compare Psalms 37:18.

125. See L.M. Muntingh, The Social and Legal Status of A Free Ugaritic Female, $26 \mathrm{~J}$ Near E Studies 102, 111 (1967), and above, note 120.

126. See Thompson, 18 Vetus Testamentum at $97-98$ (cited in note 19).

127. Thomas, ed, Documents from Old Testament Times (cited in note 14). 
property by intestate succession, and, second, said nothing about a widow's distributing inherited property either to her husband's relatives or to her own. ${ }^{128}$

Finally, one text suggests that a man might bequeath property both to a slave, and to his natural sons. "A slave who deals wisely will rule over a son who acts shamefully, and will share the inheritance as one of the brothers." (Prov. 17:2). ${ }^{129}$ This situation is not the same one as in Genesis 15:3-4 which suggests that a slave born in the house of a childless father might inherit his property. ${ }^{130}$ Here, it is a matter of a good slave ${ }^{131}$ sharing an inheritance along with his master's sons. It is likely that he would do so only if the master had so arranged by making a special bequest.

\section{Conclusions}

Previous accounts of inheritance in biblical law and tradition generally have not distinguished between inheritance by operation of law (or intestate succession) and transfer of property by bequest. The latter topic has either been ignored or subsumed under the former. Yet the distinction, common in modern law, appears valid in describing biblical law and practice.

The law of intestate succession in Numbers 27:8-11 set out the law that was to apply when the deceased had not bequeathed his property to anyone. The order of succession or descent was as follows: first the decedent's son(s), then his daughter(s), then his brothers, then his uncles, and finally, in the absence of all of the above, his family's nearest kinsman. All the property would pass to the person or persons in each category; those next in order would take nothing if there was a surviving heir in the higher category. Thus, for example, a surviving daughter with no brothers would inherit everything, while the decedent's brothers would receive nothing. Various biblical texts, however, alter or supplement this pattern. As we have seen, one text suggests that a slave born in his master's house might inherit his property. ${ }^{132}$ If the parents had no sons but an only daughter who later

128. Compare the $N O A B$ annotator's comment, "She distributed her property, according to the Mosaic law (Num. 27:11)." $N O A B$, Apocrypha sec., at 95 (cited in note 11); $N O A B$ $N R S V$, Apocrypha sec., at 39 (cited in note 7).

129. Compare Prov. 29:21. There, however, the text is too uncertain to permit one to draw any conclusions.

130. See above, text accompanying notes 20-23.

131. Prov. 17:2 speaks of a "slave who deals wisely." In biblical wisdom writings, wisdom and goodness are closely related if not synonymous attributes.

132. See above, text accompanying note 21 . 
marries, their son-in-law would inherit everything. ${ }^{133}$ More surprisingly, is the evidence that widows-who are not mentioned in Numbers 27 -might inherit their husbands' property. ${ }^{134}$ Naomi's late husband had male relatives; yet it was she who evidently inherited his field. The widows of 2 Kings 4 and 8 apparently inherited their deceased husbands' houses, even though each had a surviving son or sons. Perhaps the understanding was that the widow had a life-interest in her husband's estate, but that on her demise it would pass to their sons or others in the order of intestate succession set out in Numbers $27 .{ }^{135}$

Clearly, bequests could be made to persons other than those identified in this law of intestate succession. That law, apparently, was not regarded as controlling with regard to bequests. Bequests could be left to widows, daughters along with sons, slaves, and possibly grandchildren. Moreover, a widow might bequeath property not only to her husband's relatives, but also to her own. ${ }^{136}$

Bequests were not, however, in the form of modern wills, i.e., testamentary instruments or documents signed or "executed" by the testator and intended to become effective upon the testator's death. Instead, typically, the biblical testator, without any discernible formalities, simply gave property to the donees or devisees or stated that he had already done so. In most instances, such gifts were made when the testator or donor expected that he or she would die in the somewhat near (though not necessarily imminent) future. ${ }^{137}$

Though these conclusions may be reasonably likely, a number of issues remain unsettled. Possibly research into laws and customs of other ancient Near Eastern cultures may shed further light on these questions. It is probable, however, that we shall not find definitive answers to all of them, simply because the evidence is insufficient to justify final conclusions.

We have noted instances where widows with sons apparently in-

133. See above, text accompanying notes 29-34. It is unclear what would happen if parents had no sons, but more than one daughter and one daughter married while the others remained single.

134. See above, text preceding and accompanying notes $35-51$.

135. In Naomi's case, levirate marriage custom evidently provided that she might sell the inherited property to her deceased husband's nearest kinsman if that kinsman also married her-or by extension, the widow of one of her sons-in order "to restore the name of the dead to his inheritance." (Ruth 4:5). Presumably, the son born of this marriage would not immediately inherit, i.e., take possession of the redeemed property, the day he was born. Perhaps he would do so only upon the death of his biological or surrogate father.

136. See above, text preceding note 128 .

137. See above, text accompanying notes $107-20$ and following 120 . 
herited their husbands' property. ${ }^{138}$ At what point would such sons obtain their father's property? Was there some age of majority? Or would the widowed mother continue to hold or control the property until she died or remarried? If she remarried, would the sons then take their father's property, or would it pass to the second husband?

A somewhat similar set of questions arises with respect to sons by levirate marriage. Would such sons "inherit," that is, take possession of their nominal father's property when they reached some age of majority, or would their biological (or "surrogate") father hold it for them until his demise? When the biological father died, would the first-born son by levirate marriage inherit some of his property, thus taking away from what the father's "own" sons, if any, would have inherited; or would the first-born son by levirate marriage inherit only the redeemed property that had belonged to their nominal father? If there should be more than one son by levirate marriage, would the older (or oldest) take all, or only a double portion; or would such sons share the inheritance equally? ${ }^{139}$ What would happen if the deceased's property was redeemed and the levirate marriage was blessed with daughters, but no son? ${ }^{140}$ Would such daughters inherit the redeemed property? Would only the first-born daughter inherit, or would all such daughters be considered heiresses for purposes of Numbers 27 and 36 ?

In the case of the Jubilee year laws, was it expected that the original owner himself would return to the property after forty-nine years, or was it understood that his heir or heirs would do so if he had died in the meantime? In the case of multiple heirs, would the original property be partitioned among them, or would it be kept intact? (Or had the planners for the Jubilee year neglected to contemplate this problem?) Was it expected that the Jubilee year would be repeated every fifty years, or was it to be observed only once? ${ }^{141}$ In either

138. See above, text preceding and accompanying notes 44-45.

139. Westbrook speculates that "all the sons of the levirate union shared in the inheritance of the deceased." The Law of the Biblical Levirate, $24 \mathrm{R}$ Intl des Droits de L'Antiquite 3d Ser at 79-80 (cited in note 8), reprinted in Westbrook, Property and the Family at 69 (cited in note 3). But see C.J.H. Wright, Family, in 2 Anchor Bible Dictionary 763 (Doubleday, 1992) (suggesting that other sons would be heirs to the levir's property).

140. See above, note 28.

141. The Jubilee year laws do not specify that the Jubilee year was to be repeated every fifty years, but refer instead to the year of Jubilee. Yet a cycle seems implicit in the provisions synchronizing the Jubilee year with the series of Sabbatical years in Lev. 25:1-10, and scholars generally assume that the law intended that the cycle be repeated throughout history. Later Judaism understood that the cycles were to have been repeated. 14 Encyclopedia Judaica 581. 82 (Keter Pub, 1972). 
event, what was to be the base year from which the fiftieth year would be reckoned?

Finally, as to the birthright: it is reasonable to infer from Deuteronomy 21:15-17 that at some point in the biblical period, the first-born son could expect to receive a double portion of his father's estate, whether by inheritance or bequest, as a matter of custom. Yet allocation of a double portion is not attested by any other biblical text. The question remains, then, to what extent such a birthright tradition or practice was actually observed during the biblical period. 
